\title{
Factors associated with abnormalities of the cytopathological uterine cervix test in South of Brazil
}

Willian Augusto de Melo 1

Sandra Marisa Pelloso 2

Aline Alvarenga 3

Maria Dalva de Barros Carvalho 4

${ }^{1}$ Centro de Ciências da Saúde. Universidade Estadual do Paraná. Campus Paranavaí. Av. Gabriel Espiridião s.n. Paranavaí, PR, Brasil. CEP: 97.703-000. E-mail: willian.enfer@gmail.com

2,4 Programa de Pós-graduação em Ciências da Saúde. Centro de Ciências da Saúde. Universidade Estadual de Maringá. Maringá, PR, Brasil.

3 Egressa do Centro Universitário de Maringá. Maringá, PR, Brasil.

\begin{abstract}
Objectives: to identify factors associated with abnormal cytopathological test uterine cervix

Methods: it is a analytical study with the participation of 390 women who presented abnormal cytopathological from a city in the state of Parana in 2012. They were randomly selected through sampling plan. Sociodemographic information such as age, marital status, education level and ethnicity were considered independent variables while the high or lowgrade cytological lesions as dependent variable. We analyzed the data statistically by Yates Corrected test, Fisher exact test and measures of association by odds ratio. For all analyzes was considered significance level of $5 \%$ and $95 \%$ confidence interval.

Results: the mean age was 38.8 years, $72.9 \%$ were married or common-law marriage, $49.7 \%$ with low education level and $87.4 \%$ race/color white. HPV contamination was detected in $49.7 \%$ of women and high-grade cytological lesions in 18.2\%. The low educational level $(95 \% O R=4.07)$ and non-white ethnicity $(95 \% O R=2.22)$ were strongly associated with the development to cervical lesions ( $p<0.05)$.

Conclusions: sociodemoghaphic characteristics were crucial to high-risk lesions and development of cervical cancer, especially in women with low educational level and race/color black or brown. These results confirm the persistence of diseases related to preventable and avoidable causes in the country.

Key words Uterine cervical neoplasms, Women's health, Epidemiology
\end{abstract}




\section{Introduction}

Despite the knowledge and advances of medicine, more specifically in the oncology area, cancer remains a difficult disease to be understood, being considered in most of the industrialized world as an enigmatic disease and with not totally efficient treatments. 1

Cancer can be associated with several factors related to the external and internal environment. The external factors are related to the environment and the internal factors are those genetically predetermined, in other words, when the organism has the capacity to defend itself from the external aggressions. ${ }^{2-3}$

Cervical cancer is a disease that has a high potential for prevention and cure when diagnosed early. It is usually asymptomatic and its evolution is slow through detectable and curable preclinical stages. $4-5$

The period of precursor lesions for cervical cancer, designated as asymptomatic and curable, is known as cervical intraepithelial neoplasia (CIN) II and CIN III and also Adenocarcinoma in situ (AIS). Regarding CIN, it is defined as a cytomorphological expression of a temporary infection caused by the Human Papillomavirus (HPV) possessing great chances of regression and therefore is not considered as precursor lesion. 3,5

In Brazil, cervical cancer is the third most common type of cancer. In 2016, 16,340 cases were estimated, with an estimated risk of 15.8 cases per 100,000 women. 5 In the State of Paraná, estimates for the year 2016 were 860 new cases, with a crude incidence rate of 14.9 cases per 100,000 inhabitants. 5

Cervical cancer usually affects the groups with the greatest social vulnerability, where the greatest barriers to access to the service network are observed, for early detection and treatment of the disease due to economic and geographical difficulties, lack of services and cultural issues, such as fear and prejudice from the companion. ${ }^{4}$

According to the Brazilian Society of Cancerology (SBC), in addition to the number of partners, early initiation of sexual activity, smoking, sexually transmitted diseases, use of oral contraceptives and poor nutrition in some nutrients, the incidence of cervical cancer increases as the number of children is higher. In addition to the low socioeconomic level, which encompasses poverty and low schooling, the age of the first gestation is also focused, since women who give birth at an early age are more likely to develop this disease than those within the most adequate age at first pregnancy. ${ }^{6}$

Considering the importance of identifying factors associated with cervical cancer in order to plan policies and actions in the prevention and promotion of health, this study aimed to identify the factors associated with the cytological abnormalities of the cervical-uterine cytopathological examination.

\section{Methods}

This is a cross-sectional, analytical and epidemiological study. The study was developed in the municipality of Colorado, city located in the Northwest region of the State of Paraná, Brazil. It has a population of 22,345 inhabitants, of which 11,303 (50.6\%) are women. 7 The primary health care of the municipality is composed of six Basic Health Units, and Central Health Unit II was selected for data collection because it is considered reference for the preventive actions of cervical cancer.

The choice of this municipality was motivated by the high proportions of hospitalizations due to tumor lesions of the uterine cervix ("malignant neoplasm, neoplasia in other unspecified portions, carcinoma in situ and leiomyoma") when compared to the other tumors. According to data from the Ministry of Health, available by the Department of Informatics of the Unified Health System (DATASUS), from 2008 to 2010, an average of $34.2 \%$ of neoplasms in women in the city was related to the uterine cervix, ${ }^{8}$ while in the State of Paraná, this average was $21.2 \% .9$

The sampling plan was performed from the simple random sampling and calculated by the Epiinfo program version 7.2,10 making an initial sample of 290 women, from which they were randomly selected from the universe of 1,186 women who had undergone the cytopathological examination in the municipality.

Using the formula $N=[p(1-p)]^{*} z^{2} / d^{2}$; where $p$ is the proportion in women who underwent cytopathological examination; (1-p) proportion of women who presented cytological abnormalities in the cytopathological examination; $\mathrm{z}$ is the percentile of the standardized normal distribution, based on the confidence that is desired from the outcome variable (whether or not presenting cytological abnormalities) in the population; $d$ is the maximum amplitude for the absolute value of the difference between estimate and population value, adjusted by a correction factor for finite populations. An estimate error of 5\% and $95 \%$ of confidence and precision of the sample was considered, percentage of $50 \%$ was adopted, which provides the maximum sample size and with 
these parameters the number of 290 women was obtained.

Women's records were used as secondary data source, which was made available by the Municipal Health Department, from the 390 women who underwent the cytopathological examination in 2010 and who presented a positive result for cytological abnormalities. We began data collection after the selection of medical records and the active search report in SISCOLO (Cervical Cancer Control Information System) attached to the respective medical records. The period of data collection occurred between June and August 2011.

To compose the dependent variable, we adopted the cytopathological criteria described by Kurman and Solomon11 in an official publication of the Bethesda System. Considering that all women had cytopathologic abnormalities, in this study, were considered only the non-negative diagnostic group that included subgroups 3 and 4. Subgroup 3, called Low Grade Lesions, included cytopathological abnormalities compatible with human papillomavirus (HPV) and cervical intraepithelial neoplasia grade I (CIN I) and subgroup 4, called High Grade Lesions (CIN II) and III (CIN III), invasive squamous cell carcinoma (SCC), in situ adenocarcinomas, and invasive adenocarcinoma.

Sociodemographic data were considered as independent variables. Age was categorized in $<25$ years, 25 to 59 years and 60 years or more, the second being considered as the priority age range for cytopathological examination. ${ }^{4}$ Marital status was categorized as single, married, widowed and separated and later dichotomized as with or without partner. The educational level was categorized as without study, from 4 to 7 years, 8 to 11 and 12 or more years of study, being dichotomized in $<8$ years and $\geq$ to 8 years of school education. For ethnicity we consider colors white, black, brown and yellow, being dichotomized in white and non-white. The dichotomizing of the variables were performed to allow greater analytical rigor and to control the effects of interest arising from the association between dependent variable and independent variables.

All information collected was transcribed, coded and tabulated in an Excel for Windows ${ }^{\circledR}$ worksheet. For univariate analysis we performed descriptive analyzes from the frequency tables, with percentage distributions and interval estimates of proportion for categorical variables and the calculation of measures of central tendency as means and standard deviations for numerical variables.

The statistical tests used for bivariate analysis were the Pearson chi-square test and, for contingency tables that presented cells with values lower than six, Fisher's Exact Test. The adjusted Odds Ratio (OR) was also estimated for each association of interest. For all analyzes, was considered a significance level of $5 \%$ and a $95 \%$ confidence interval (CI95\%). Statistical tests were carried out using EpiInfo software version 7.2.10

This study was approved by the Standing Committee on Ethics in Research Involving Human Beings of the University Center of Maringá (UniCesumar), under recommendation number $166 / 2010$ pursuant to resolution $466 / 2012$ of the National Health Council.

\section{Results}

Women in this study had a mean age of 38.8 years \pm 9.2 (standard deviation). The prevalent age range was 25 to 59 years, with a total of $91.54 \%$. The youngest was 17 and the oldest 68 years old. With regard to the other sociodemographic variables, $72.8 \%$ lived with a partner (married or in stable union) and had low level of schooling (42.8\%), that is, less than 8 years of study. Regarding ethnicity, white women prevailed (87.4\%) (Table 1).

Among the women studied, $79.7 \%$ had lowgrade lesions. HPV contamination, detected in $49.7 \%$, and intracellular neoplasia I (28.5\%) stood out in this group. Among the high-grade lesions, the highest prevalence were cases of intracellular neoplasia II (17.5\%) (Table 2).

Through the bivariate analysis it was evidenced that women with low level of education $(\mathrm{OR}=4.07$, $\mathrm{CI} 95 \%=2.06-8.16)$ and non -white race/color $(\mathrm{OR}=2.22, \quad \mathrm{CI} 95 \%=1.05-4.65)$ were the sociodemographic aspects that showed association for the involvement of high grade lesions (Table 3 ). The group of women aged 25-59, considered the most vulnerable age group, although it corresponded to most of the women, showed no association with high grade lesions.

\section{Discussion}

Having a low level of schooling and non-white color/race were the main determinants for the involvement of high grade cytological abnormalities in the uterine cervix in the studied women.

Educational level was a determining factor of greater relevance found in this study. Considering that $57.2 \%$ of women had a low level of schooling, it was statistically confirmed because they had four times more chance to be affected by high grade 
Table 1

Distribution of sociodemographic variables of women submitted to cytopathological examination with cytological alterations.

\begin{tabular}{|c|c|c|c|}
\hline Sociodemographic variables & $\mathbf{N}$ & $\%$ & $\mathrm{Cl} 195 \%$ * \\
\hline \multicolumn{4}{|l|}{ Age (years) } \\
\hline$<25$ & 29 & 7.4 & $5.2-10.5$ \\
\hline 25 a 59 & 357 & 91.5 & 88.4-93.9 \\
\hline 60 or more & 4 & 1.0 & $0.4-2.6$ \\
\hline \multicolumn{4}{|l|}{ Marital status } \\
\hline Single & 65 & 16.7 & $13.3-20.7$ \\
\hline Married & 284 & 72.8 & $68.2-77.0$ \\
\hline Widower & 16 & 4.1 & $2.5-6.6$ \\
\hline Separated & 25 & 6.4 & $4.4-9.3$ \\
\hline \multicolumn{4}{|l|}{ Educacional level } \\
\hline Illiterate & 6 & 1.5 & $0.7-3.3$ \\
\hline From 4 to 7 years of schooling & 217 & 55.6 & $50.7-60.5$ \\
\hline From 8 to 11 years of schooling & 165 & 42.4 & $37.5-47.3$ \\
\hline 12 or more years of schooling & 2 & 0.5 & $0.1-1.9$ \\
\hline \multicolumn{4}{|l|}{ Ethnicity } \\
\hline White & 341 & 87.5 & $83.8-90.4$ \\
\hline Black & 23 & 5.9 & $4.0-8.7$ \\
\hline Brown & 25 & 6.4 & $4.4-9.3$ \\
\hline Yellow & 1 & 0.3 & $0.0-1.4$ \\
\hline Total & 390 & 100.0 & - \\
\hline
\end{tabular}

*Confidence interval for proportion.

Table 2

Distribution of clinical variables of women submitted to cytopathological examination according to age group.

\begin{tabular}{|c|c|c|c|c|c|c|c|c|}
\hline \multirow[t]{2}{*}{ Clinical variables } & \multicolumn{2}{|c|}{$<25$ years } & \multicolumn{2}{|c|}{25 to 59 years } & \multicolumn{2}{|c|}{$\geq 60$ years } & \multicolumn{2}{|c|}{ Total } \\
\hline & $\mathrm{n}$ & $\%$ & $\mathrm{n}$ & $\%$ & $\mathrm{n}$ & $\%$ & $\mathrm{n}$ & $\%$ \\
\hline Negative - & - & 6 & 1.5 & - & - & 6 & 1.5 & \\
\hline Proven HPV & 10 & 2.6 & 183 & 46.9 & 1 & 0.3 & 194 & 49.7 \\
\hline CIN I & 15 & 3.8 & 95 & 24.4 & 1 & 0.3 & 111 & 28.5 \\
\hline CIN II & 2 & 0.5 & 33 & 8.5 & - & - & 35 & 9.0 \\
\hline CIN III & 1 & 0.3 & 23 & 5.9 & 1 & 0.3 & 25 & 6.4 \\
\hline Invasive Squamous Carcinoma & - & - & 1 & 0.3 & - & - & 1 & 0.3 \\
\hline Adenocarcinoma in situ & - & - & 5 & 1.3 & 1 & 0.3 & 6 & 1.5 \\
\hline Adenocarcinoma invase & - & - & 1 & 0.3 & - & - & 1 & 0.3 \\
\hline Unsatisfactory* & - & - & 2 & 0.5 & - & - & 2 & 0.5 \\
\hline Did colpocitology* & - & - & 2 & 0.5 & - & - & 2 & 0.5 \\
\hline No treatment* & - & - & 2 & 0.5 & - & - & 2 & 0.5 \\
\hline Not found* & - & - & 4 & 1.0 & - & - & 4 & 1.0 \\
\hline Total & 29 & 7.4 & 357 & 91.5 & 4 & 1.0 & 390 & 100.0 \\
\hline
\end{tabular}

HPV= human papillomavirus; $\mathrm{CIN}=$ cervical intraepithelial neoplasia; * Variables excluded from the statistical analyses (Tables 3 ). 
Bivariate analysis of lesions of low and high degree of cytological abnormalities according to sociodemographic variables of women.

\begin{tabular}{|c|c|c|c|c|c|c|c|c|c|}
\hline \multirow[t]{2}{*}{ Sociodemographic variables } & \multicolumn{2}{|c|}{ High grade lesions } & \multicolumn{2}{|c|}{ Low grade lesions } & \multicolumn{2}{|c|}{ Total } & \multirow[t]{2}{*}{$\mathrm{OR}^{*}$} & \multirow[t]{2}{*}{$\mathrm{Cl} 95 \%{ }^{\dagger}$} & \multirow[t]{2}{*}{$p \S$} \\
\hline & $\mathrm{n}$ & $\%$ & $\mathrm{n}$ & $\%$ & $\mathrm{n}$ & $\%$ & & & \\
\hline \multicolumn{10}{|l|}{ Age (years) } \\
\hline$<25$ & 4 & 1.1 & 25 & 6.6 & 29 & 7.7 & 0.72 & $0.24-2.14$ & 0.555 \\
\hline 25 a 59 & 63 & 16.6 & 284 & 74.7 & 347 & 91.3 & 1 & & \\
\hline 60 or more & 2 & 0.5 & 2 & 0.5 & 4 & 1.0 & 4.50 & $0.31-62.8$ & $0.157 \ddagger$ \\
\hline \multicolumn{10}{|l|}{ Marital status } \\
\hline Without partner & 17 & 4.5 & 85 & 22.4 & 102 & 29.9 & 0.86 & $0.47-1.58$ & 0.647 \\
\hline With partner & 52 & 13.6 & 226 & 59.5 & 278 & 73.1 & 1 & & \\
\hline \multicolumn{10}{|l|}{ Educacional level } \\
\hline$<8$ years of schooling & 56 & 14.7 & 160 & 42.1 & 216 & 56.8 & 4.06 & $2.13-7.73$ & $<0.001$ \\
\hline$\geq 8$ years of schooling & 13 & 3.5 & 151 & 39.7 & 164 & 43.2 & 1 & & \\
\hline \multicolumn{10}{|l|}{ Ethnicity } \\
\hline White & 14 & 3.7 & 32 & 8.4 & 46 & 12.1 & 2.21 & $1.11-4.43$ & 0.021 \\
\hline No white & 55 & 14.5 & 279 & 73.4 & 334 & 87.9 & 1 & & \\
\hline Total & 69 & 18.2 & 311 & 81.8 & 380 & 100.0 & & & \\
\hline
\end{tabular}

*Odds Ratio; § Descriptive level for Pearson's chi-square; + Confidence interval (95\%); ₹ Descriptive level for Fisher's exact test.

lesions when they belong to this group.

A study of 134 adolescents in the city of São Paulo showed that maternal schooling did not positively influence the cytopathological examination $(p<0.001)$, even at the recommended periodicity $(p<0,05) .12$ This result differed from the present study, possibly due to the characteristics of the subjects participating in the two studies, especially in relation to the age group, once the lower the age is, the greater the degree of dependence of the subjects and consequently the shorter the years of studies completed.

On the other hand, a study that aimed to identify and analyze socioeconomic, behavioral and biological characteristics of women with cervical cancer in southern Brazil found that $45 \%$ of the interviewees hadn't complete elementary school, that is, less than eight years of studies completed. 13

Other studies also indicate the educational level as a sociodemographic factor strongly associated with the development of cytopathological alterations and also with the non-accomplishment of cytopathological examination. 14-16

Lastly, it was evidenced that schooling is one of the risk factors for the development of Uterine Cervical Cancer presenting a high mortality rate in the most varied age groups, with peak incidence of carcinoma in situ between 25 and 55 years. 17

In this study, nonwhite women were twice as likely to develop high-risk cytologic lesions when compared to white women.

In contrast, in the state of Mato Grosso, a study aimed at analyzing the sociodemographic and clinical factors most associated with the development of precursor lesions of invasive carcinoma, did not verify statistical significance of ethnicity to influence the occurrence of cancer lesions in uterine cervix. ${ }^{18}$

This difference in results can be justified by the demographic characteristics of the two States. According to IBGE data, the state of Paraná has a white population three times larger than the nonwhite population $(7,344,122$ and 2,951,208 respectively), and in the State of Mato Grosso the non-white population is slightly larger than the white population (1.820597 e 1.137.150 respectively). This proportionality between white and non-white population in the state of Mato Grosso, did not represent statistical significance for race/color.

A similar study carried out in the city of São Paulo found that $15 \%$ of the women who presented high grade lesions were non-white, however, there was no statistical significance of this variable with occurrence of high grade lesion ( $p=0.674$ ). The same author emphasizes the inequalities of race/color in the accomplishment of the cytopathological examination, mainly those inserted in a low socioeconomic class. 19 
In the year 2008, in Recife-PE, being of non-white color was categorized as the highest risk of mortality, this was observed in $60.5 \%$ of deaths due to cervical cancer occurred in black women. ${ }^{14}$

A study carried out in Pelotas-RS indicates that the race/color variable is associated with the nonaccomplishment of the cytopathological exam of uterine cervix. ${ }^{15}$

Although there is no biological explanation, nonwhite women present higher cervical cancer mortality, ${ }^{19}$ however, some studies indicate that "race/color" variable is associated with socioeconomic factors such as the low family income and that contribute to the phenomena of nonaccomplishment of the cytopathological exam and the increased risk of developing high-grade lesions. 14,19

Most of the population's problems do not depend directly on high technology for their prevention or control but on the assumption of responsibility by health professionals as to their role as educators and builders of a sanitary awareness conscience within women, encouraging them to practice preventive screening and strengthening their social participation in the process. In this way, the importance of planning in the educational, social, political and economic areas is reinforced for the implementation of policies to prevent cervical cancer.4-5,20

In this study, age did not represent a risk factor for the development of significant cytological abnormalities. One possible explanation is that there was a higher prevalence of HPV and CIN I in the age group of 25 to 59 years, inferring that, being considered as an age group at risk for the development of cervical cancer, as recommended by the Ministry of Health, this study was not confirmed.

Other studies, carried out on mortality among women, show that cervical cancer, despite having a drop in the standardized mortality rates, is high in the most varied age groups, with the peak incidence of carcinoma in situ being between 25 and 40 years and invasive carcinoma between 48 and 55 years. ${ }^{21}$

Marital status had no influence in determining risk for high-grade lesions, but it is important to highlight studies that confirmed that having no partner is a risk factor for cervical cancer mortality. 14-15,22

On this basis, there is a need to reinforce the importance of health education, especially sex education. Women with lower schooling, low family income, mulatto or black race/color and with age between 20 and 29 years present a higher relative risk of not performing the preventive examination of cervical cancer in relation to those older than 30 years. ${ }^{23}$

Health education becomes essential when we look at cervical cancer prevention, and educational and preventive actions need to be developed in a continuous way in women's lives, as well as to plan actions that facilitate women's access and shelter in the health services. ${ }^{13,24}$ Health professionals must be committed to their role as educators and agents that transform reality, contributing to the reduction of the problem, through the prevention of disease and the promotion of women's health. 24

These results confirm that avoidable and reducible diseases still persist in the country, and higher efforts are needed in order to increase health promotion and prevention, control and care for noncommunicable diseases. This persistence occurs even in the South region of Brazil, considered as one of the most developed in the country.

The sociodemographic characteristics of women who underwent cytopathological examination were determinant factors for the presence of lesions with high risk of development of cervical cancer, especially in women with low schooling and nonwhite race/color.

The limitations of cross-sectional studies, especially when a secondary data source has been used, need to be considered. Due to the inexistence or inconsistency of records, it was not possible to analyze the existence of dependence between cytological lesions and other risk factors like sociodemographic variables, such as income and employment; gynecological variables, such as early or late menarche and number of children, and behavioral variables such as lifestyle or adherence to healthy habits.

Considering that cervical cancer generates great changes in the life of women, also influencing family life, and that most of them are in the reproductive phase of life, it is emphasized that their prevention is relatively cheap when taken into consideration the cost-benefit ratio. This can be an impact factor for a developing country like Brazil, where cervical cancer presents high mortality rates and remains being a serious public health problem.

It is worth mentioning the promotion, development and implementation of programs related to health education, with the aim of reorganizing the health services in primary care, contemplating integrality of care. There is a need to foster greater interaction among health professionals, in order to transform their praxis into uninterrupted attitudes of educational and preventive actions. 


\section{References}

1. Tavares JSC, Trad LAB. Metáforas e significados do câncer de mama na perspectiva de cinco famílias afetadas. Cad Saúde Pública. 2005; 21 (2): 426-35.

2. Servantes LF. Terapia Ocupacional: pesquisa e atuação em oncologia. Campo Grande: UCDB; 2002.

3. Pinotti JA, Barros ACSD. Ginecologia Moderna: Condutas da Clínica Ginecológica da Faculdade de Medicina da USP. São Paulo: Revinter; 2003

4. Instituto Nacional do Câncer (INCA), dados dos registros de câncer de base populacional [Internet]. Rio de Janeiro; 2016 [acesso em 10 mar 2016]. Disponível em: http://www.inca.gov.br/regpop/2003/index.asp?link=localizacoes.asp $\&$ ID $=5$

5. Instituto Nacional do Câncer (INCA). Estimativa 2016: Incidência de câncer no Brasil. [Internet]. Rio de Janeiro; 2016 [acesso 24 mar 2017]. Disponível em http://www.inca.gov.br/estimativa/2016/estimativa-2016v11.pdf

6. Sociedade Brasileira de Cancerologia. Câncer ginecológico. Colo de útero. [Internet]. 2016 [acesso 25 mar 2017]. Disponível em: http://www.sbcancer.org.br/wpcontent/uploads/2016/10/cancer-ginecologico.pdf

7. Instituto Brasileiro de Geografia e Estatística. Cidades [Internet]. 2016 [acesso em 10 mar 2016]. Disponível em: http://www.ibge.gov.br/cidadesat/topwindow.htm?

8. Brasil. Ministério da Saúde. Departamento de Informática do Sistema Único de Saúde - Datasus. TABNET Morbidade hospitalar do SUS por local de residência. Colorado, Paraná, Brasil. 2017 [acesso em 22 mar 2017] Disponível

em: http://tabnet.datasus.gov.br/cgi/tabcgi.exe?sih/cnv/nrpr.def

9. Brasil. Ministério da Saúde. Departamento de Informática do Sistema Único de Saúde - Datasus. TABNET; Morbidade hospitalar do SUS por local de residência Estado do Paraná, Brasil. 2017 [acesso em 22 mar 2017]. Disponível em: http://tabnet.datasus.gov.br/cgi/tabcgi.exe?sih/cnv/nrpr.def

10. Center For Disease Control. Epi Info versão 7.2 [Internet] Atlanta: CDC; 2016 [acesso em 5 jan 2016]. Disponível em: https://www.cdc.gov/epiinfo/pc.html

11. Kurman RJ, Solomon DO. Sistema Bethesda para o relato de diagnóstico citológico cervicovaginal. Rio de Janeiro: Revinter; 1997.

12. Cirino FMSB, Nichiata LYI, Borges ALV. Conhecimento, atitude e práticas na prevenção do câncer de colo uterino e HPV em adolescentes. Esc Anna Nery Rev Enferm. 2010 14 (1): 126-34.

13. Soares MC, Mishima SM, Meincke SMK, Simino GPR Câncer de colo uterino: caracterização das mulheres em um município do sul do Brasil. Esc Anna Nery Rev Enferm. 2010; 14 (1): 90-6.

Received on March 10, 2016

Final version presented on June 20, 2017

Approved on July 4, 2017
14. Mendonça VG, Lorenzato FRB, Mendonça JG, Menezes TC, Guimarães MJB. Mortalidade por câncer do colo do útero: características sociodemográficas das mulheres residentes na cidade de Recife, Pernambuco. Rev Bras Ginecol Obstet. 2008; 30 (5): 248-55.

15. Hachkenhaar AA, Cesar JÁ, Domingues MR. Exame citopatológico e colo uterino em mulheres com idade entre 20 e 59 anos em Pelotas, RS: prevalência, foco e fatores associados à sua não realização. Rev Bras Epidemiol. 2006; 9 (1): 103-11.

16. Medeiros VCRD, Medeiros RC, Moraes LM, Menezes Filho JB, Ramos ESN, Saturnino ACRD. Câncer de Colo de Útero: Análise Epidemiológica e Citopatológica no Estado do Rio Grande do Norte. RBAC 2005; 37 (4): 227 31

17. Brasil. Ministério da Saúde (BR). Secretaria de Vigilância em Saúde. Secretaria de Atenção à Saúde. Política Nacional de Promoção da Saúde. Brasília, DF; 2006.

18. Nakagawa JT, Espinosa MM, Barbieri M, Schirmer J. Fatores associados ao câncer invasivo do colo do útero no Estado de Mato Grosso. Ciênc Cuid Saúde. 2010; 9 (4): 799-805.

19. Gamberini KST, Laganá MTC, Toriyama ATM. Relação entre raça/cor e a freqüência das lesões intra-epiteliais de alto grau (NIC II e NIC III). Saúde Coletiva. 2008; 5 (20): 51-6.

20. Rivoire WA, Capp E, Corleta HE, Silva ISB. Bases biomoleculares da oncogênese cervical. Rev Bras Cancerol. 2001; 47 (2): 179-84.

21. WCN, Women's Câncer Network. Gynecologic Information [internet]. Chicago, Il: Hologic; 2010; [acesso 13 out 2010]. Disponível http://www.wcn.org/downloads/Understand_CC.pdf

22. Martins LFL, Thuler LCS, Valente JG. Cobertura do exame de Papanicolaou no Brasil e seus fatores determinantes: uma revisão sistemática da literatura. Rev Bras Ginecol Obstet. 2005; 27 (8): 485-92.

23. Cesar JA, Horta BL, Gomes G, Houlthausen RR, Willrich $\mathrm{RM}$, Kaercher A, et al. Fatores associados à não realização de exame citopatológico de colo uterino no extremo Sul do Brasil. Cad Saúde Pública. 2003; 19 (5): 1365-72.

24. Greenwood SA, Machado MFAS, Sampaio NMV. Motivos que levam mulheres a não retornarem para receber o resultado de exame Papanicolau. Rev Latino-am Enferm. 2006; 14 (4): 503-9. 